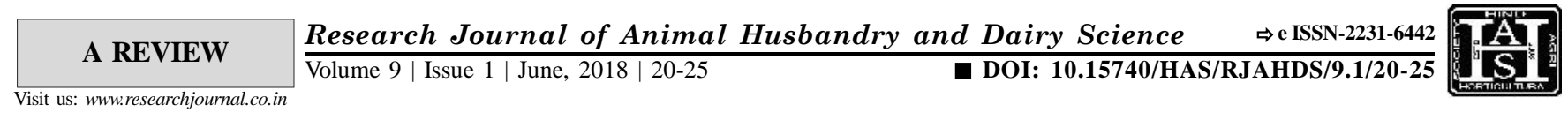

\title{
Strategies for conservation and improvement of indigenous cattle breeds in Gaushalas
}

\author{
Kalyan Mandi, S. Subash and M.C.A. Devi
}

\begin{abstract}
Gaushalas in India are synonymous with the protection of cows and cattle wealth of the country. It is primarily occupied with providing shelter to cows and is catering mostly the needs of non-lactating, weak, unproductive and stray cattle. However, a few fore front Gaushalas are striving to maintain nucleus herd for in-situ conservation of indigenous purebred cows and produce quality males so as to enhance productivity of indigenous breeds.Indigenous cattle are suited to tropical climatic conditions, are able to resist the heat stress, need less water, can walk long distances, survive on local grasses and resist tropical diseases. However, genetic erosion of indigenous cattle breeds is a problem of national concern and a number of local breeds are at a risk of extinction. Currently, the indigenous/non-descript cattle contribute about 21 per cent of total milk production in the country. However, given proper attention, the contribution of these animals can be increased substantially. In this regard; recently, several measures have been initiated by the Gaushalas to increase the productivity of milch animals in their native tracts. Under this background, various breeding and reproductive technologies for selection and faster multiplication of genetically superior cattle have been adopted by few progressive Gaushalas to conserve our elite indigenous germplasm. Therefore, an integrated approach with due consideration to proper feeding, breeding, healthcare and improved management practices are recommended to address the future challenges in Gaushalas and exploit potential for sustainable conservation of our native breeds.
\end{abstract}

KEY WORDS : Gaushalas, Indigenous cattle, Conservation, Sustainable

HOW TO CITE THIS PAPER : Mandi, Kalyan, Subash, S. and Devi, M.C.A. (2018). Strategies for conservation and improvement of indigenous cattle breeds in Gaushalas. Res. J. Animal Hus. \& Dairy Sci., 9(1) : 20-25 : DOI: 10.15740/HAS/RJAHDS/9.1/20-25. Copyright@ 2018: Hind Agri-Horticultural Society.

Address for correspondence :

Kalyan Mandi, Southern Regional Station, ICAR-NDRI, Bengaluru (Karnataka) India

Email : kalyan.mandi@gmail.com

Associated Authors' :

S. Subash and M.C.A. Devi, Southern Regional Station, ICAR-NDRI, Bengaluru (Karnataka) India

Email : deviram66@gmail.com 